\title{
Physical Activity among Preclinical Medical Students at The University of Malaya, Malaysia
}

\author{
*Maryam Al-Asousi and Farouk El-Sabban \\ Department of Food Science and Nutrition, College of Life Sciences, Kuwait University, State of Kuwait
}

Received: May 10, 2016; Accepted: May 18, 2016; Published: June 16, 2016

*Corresponding author: Maryam Al-Asousi, PhD, Department of Food Science and Nutrition, College of Life Sciences, Kuwait University,

P.O. Box 5969 - Safat 13060, Kuwait City, State of Kuwait, Tel: +965-2463-3197; Fax: +965-2251-3929; E-mail: mrymfhd@hotmail.com

\begin{abstract}
Medical students should have knowledge of the benefits of healthy lifestyle, so that they can advise their future clients. This study was carried out to assess the physical activity level among students in the preclinical phase at the University of Malaya, Malaysia. The study involved 150 males and 100 female students - who responded to a questionnaire that included three main categories: demographics, nutrition, and physical activity. Students represented different ethnic backgrounds and provinces of Malaysia. Most students (90\%) lived and dined on campus, $62 \%$ ate 3 meals/day, $63 \%$ felt that their nutrition was proper, $50 \%$ used nutritional supplements, and $64 \%$ had a normal BMI. As for physical activity; $76 \%$ of students exercised regularly, and $63 \%$ preferred to exercise in groups. Those who exercised had different activity levels, with a gender difference in favor of males $(\mathrm{P}<0.001)$. Students with at least one parent being physically-active were significantly influenced to exercise $(\mathrm{P}<0.001)$. Students who did not exercise cited lack of time (62\%) and laziness $(38 \%)$ as reasons. Enhancing knowledge and significance of healthy lifestyle can be instrumental in increasing the percent of exercising medical students, with an attitude that would benefit them and those whom they will cater for in the future.
\end{abstract}

Keywords: Exercise; Lifestyle; Medical school; Malaysia; Nutrition; Physical Activity; Preclinical

\section{Abbreviations}

BMI: Body Mass Index; SPSS: Statistical Package for Social Studies; WHO: World Health Organization.

\section{Introduction}

The World Health Organization (WHO) defines physical activity as any bodily movement produced by skeletal muscles that requires energy expenditure [1]. Regular physical activity is one of the most important practices that a person can do to stay healthy. Physical activity will not only increase one's chances of living longer; but also it can help control body weight, reduce risks for cardiovascular disease, type 2 diabetes, metabolic syndrome, some cancers. Regular exercise strengthens bones and muscles, prevent falls among older adults, improve mental health and mood, and improve the ability to do daily activities [2]. Physical inactivity and the related health problems pose an emergent threat to public health [3].

Although behaviors of students are considered a temporary part of college life; however, unhealthy habits picked up at this stage can persist in adult life [4]. Therefore, university and college years represent an important opportunity to students for learning about healthy lifestyle and enhancing nutritional awareness. Medical students can learn and derive the most benefit of a healthy lifestyle, by virtue of the nature of their studies [5]. It is presumed that medical students have substantial knowledge about physical activity and its benefits and, as health care professionals-to-be, they will have an influence on their patients' attitude towards the need for a regular physical activity program and an ethical obligation to prescribe suitable exercises. It is well known that there is a direct correlation between physical activity level in medical students and the medical advice they provide to their patients [6-9]. However, there is no evidence to indicate that this knowledge translates into practice in terms of maintaining good health. The structure of medical education itself is likely to cause disruption to students' health habits [10]. Staying physically-active during medical school is one of the hardest things to do; as with busy schedules, medical students may not find the time to exercise regularly. Numerous studies on physical activity level have produced different results, often presenting a sharp contrast between medical students' knowledge about the benefits of regular physical activity and its application in everyday life [11-16]. Angyan et al. [16] reported that medical students had low physical activity levels as a result of high workload and less free time.

The purpose of this study was to acquire a quantitative account for the physical activity levels of preclinical medical students at the University of Malaya Medical Centre and to learn about the influencing factors on such activities. Also, it was of interest to acquire data on student nutrition to reveal information on the prevalent lifestyle of these students. 


\section{Methods}

\section{The University of Malaya Medical Centre}

The University of Malaya campus is located at Lembah Pantai, the Province of Selangor, a suburb of Kuala Lumpur - the National Capital of Malaysia. It is one of the government-run coeducational institutions of higher learning. The university has its own medical center, which includes the Faculty of Medicine. One of the programs being offered by the Faculty of Medicine is the Bachelor of Medicine and Surgery, which includes 3 phases. The first 2 phases are non-clinical studies lasting for 3 years while the clinical phase starts with the 4 th year and continues for 3 years. The annual medical student intake is approximately 200 from all localities in the country.

\section{Study subjects}

Study subjects were female and male medical students at the Faculty of Medicine, University of Malaya. Students were in their first 3 years of study - as at this stage of their medical curriculum, they may be less busy with their studies than their clinical years counterparts and may lead a close-to-healthy lifestyle. A total number of 250 students responded to a questionnaire that was designed for this study. With such an annual medical student intake at the Faculty of Medicine, University of Malaya, the number of students included in this study (approximately $1 / 3$ of the a 3-year intake) was considered as a representative sample.

\section{The administrated Questionnaire and Data collection}

Data collection was based on a questionnaire that was designed to fall into three main categories, which are demographics, personal nutrition, and exercising data. The questionnaire was pilot-tested with 20 students to ensure its fluency and ease of understanding inquiry points. Such a questionnaire was slightly modified and the involved survey was implemented. Each trained interviewer was available at the time when students responded to the questionnaire. Any inquiries about the meaning of a certain question were provided by the interviewers. Carrying out this work was approved by the Faculty of Medicine, University of Malaya, in 2014.

\section{Data analysis}

Data were analyzed using the Statistical Package for Social Studies (SPSS), version 17.0 (SPSS Inc., Chicago, Illinois, USA). Descriptive analyses were expressed in term of percentages. Pearson correlation coefficients were calculated to determine the relation between the independent variable (physical activity level: minutes/week) and each dependent variable (e.g.; age, gender, year of study...etc.). The level of significance for these tests was set at $\mathrm{P}<0.05$.

\section{Results}

\section{Demographic characteristics}

Demographic data are presented in [Table 1]. A total of 250 students participated in this study, $60 \%$ were males and $40 \%$ were females - with an average age of $21.1 \pm 1.2$ years. Half of the students were in their first year of study while the rest were
Table 1: Socio-demographic characteristics of respondents $(n=250)$.

\begin{tabular}{|c|c|c|}
\hline Item & No. & $\%$ \\
\hline $\begin{array}{l}\text { Gender } \\
\text { Male } \\
\text { Female }\end{array}$ & $\begin{array}{l}150 \\
100\end{array}$ & $\begin{array}{l}60.0 \\
40.0\end{array}$ \\
\hline $\begin{array}{l}\text { Age* }^{*} \\
\quad \leq 20 \\
>20\end{array}$ & $\begin{array}{l}119 \\
131\end{array}$ & $\begin{array}{l}47.6 \\
52.4\end{array}$ \\
\hline $\begin{array}{c}\text { Year of study } \\
1 \\
2 \\
3\end{array}$ & $\begin{array}{l}125 \\
68 \\
57\end{array}$ & $\begin{array}{l}50.0 \\
27.2 \\
22.8\end{array}$ \\
\hline $\begin{array}{l}\text { Ethnic background } \\
\text { Malay } \\
\text { Chinese } \\
\text { Indians } \\
\text { Others }\end{array}$ & $\begin{array}{l}120 \\
100 \\
20 \\
10\end{array}$ & $\begin{array}{l}48.0 \\
40.0 \\
8.0 \\
4.0\end{array}$ \\
\hline $\begin{array}{l}\text { Province / Region } \\
\quad \text { Peninsular } \\
\text { None Peninsular } \\
\text { N.S.** }\end{array}$ & $\begin{array}{l}221 \\
20 \\
9\end{array}$ & $\begin{array}{l}88.4 \\
8.0 \\
3.6\end{array}$ \\
\hline $\begin{array}{l}\text { Living on campus } \\
\text { Yes } \\
\text { No }\end{array}$ & $\begin{array}{l}225 \\
25\end{array}$ & $\begin{array}{l}90.0 \\
10.0\end{array}$ \\
\hline $\begin{array}{l}\text { No. of brothers or sisters } \\
\begin{array}{l}0-3 \\
4-6 \\
>6\end{array}\end{array}$ & $\begin{array}{l}154 \\
82 \\
14\end{array}$ & $\begin{array}{l}61.6 \\
32.8 \\
5.6\end{array}$ \\
\hline $\begin{array}{l}\text { Position in family } \\
\text { The only } \\
\text { First } \\
\text { Middle } \\
\text { Last }\end{array}$ & $\begin{array}{l}7 \\
89 \\
60 \\
94\end{array}$ & $\begin{array}{l}2.8 \\
35.6 \\
24.0 \\
37.6\end{array}$ \\
\hline $\begin{array}{l}\text { Any of parents work? } \\
\text { Yes } \\
\text { No }\end{array}$ & $\begin{array}{l}204 \\
46\end{array}$ & $\begin{array}{l}81.6 \\
18.4\end{array}$ \\
\hline $\begin{array}{l}\text { Any siblings at UM? } \\
\text { Not at all } \\
\text { Yes In medical } \\
\text { Yes in Other colleges }\end{array}$ & $\begin{array}{l}235 \\
4 \\
11\end{array}$ & $\begin{array}{l}94 \\
1.6 \\
4.4\end{array}$ \\
\hline
\end{tabular}

in their second and third years - 27 and $23 \%$, respectively. The majority of the study subjects (88\%) were from different locations of the Peninsular Malaysia whereas 8\% were from non-peninsular provinces. Students with the Malay and Chinese ethnic backgrounds represented 48 and $40 \%$ of subjects, respectively. Most students (90\%) lived on the University of Malaya campus. Other demographic information showed that $62 \%$ and $33 \%$ had up to 3 and $4-6$ siblings, respectively. About $3 \%$ of the participants were the only son/daughter and most of them were distributed in either the first $(38 \%)$ or last $(39 \%)$ position in their families. Only $6 \%$ of the participants had siblings at the University of Malaya. More than $81 \%$ of the participant's parents, either parent or both, were working.

\section{Nutrition information and status}

Information items on nutrition of respondent students are 


\begin{tabular}{|c|c|c|}
\hline Item & No. & $\%$ \\
\hline $\begin{array}{l}\text { Do you eat on campus? } \\
\text { Yes } \\
\text { No }\end{array}$ & $\begin{array}{l}223 \\
27\end{array}$ & $\begin{array}{l}89.2 \\
10.8\end{array}$ \\
\hline $\begin{array}{l}\text { How many meals do you eat/day? } \\
\begin{array}{l}1-2 \\
3 \\
>3\end{array}\end{array}$ & $\begin{array}{l}34 \\
156 \\
60\end{array}$ & $\begin{array}{l}13.6 \\
62.4 \\
24.0\end{array}$ \\
\hline $\begin{array}{l}\text { Do you think your nutrition is } \\
\text { proper? } \\
\text { Yes } \\
\text { No }\end{array}$ & $\begin{array}{l}158 \\
92\end{array}$ & $\begin{array}{l}63.2 \\
36.8\end{array}$ \\
\hline $\begin{array}{l}\text { Do you take any supplements? } \\
\text { Yes } \\
\text { No }\end{array}$ & $\begin{array}{l}126 \\
124\end{array}$ & $\begin{array}{l}50.4 \\
49.6\end{array}$ \\
\hline $\begin{array}{l}\text { Body Mass Index (BMI)* } \\
\text { Underweight }(<18.5) \\
\text { Normal }(18.5-22.9) \\
\text { Pre-obese }(23-27.4) \\
\text { Obese class I }(27.5-34.9)\end{array}$ & $\begin{array}{l}42 \\
160 \\
43 \\
5\end{array}$ & $\begin{array}{l}16.8 \\
64.0 \\
17.2 \\
2.0\end{array}$ \\
\hline
\end{tabular}

*BMI $\left(\mathrm{kg} / \mathrm{m}^{2}\right)$ is calculated based on WHO criteria for Asians [17].

presented in [Table 2]. The majority of students (89\%) ate on campus - most of which (62\%) ate 3 meals/day and $24 \%$ ate more than 3 meals, up to 6 . More than half of the students (63\%) perceived their nutrition as being proper and the rest $(37 \%)$ considered their diet imbalanced and inadequate because of the lack of fruits, vegetables, protein, vitamins, and contained high oil and sugar. Half of the participants took nutritional supplements, mainly: vitamins, minerals, and hormones. The Body Mass Index (BMI) was based on World Health Organization cut-offs for Asian populations guidelines [17]. The majority of students (64\%) had a normal BMI and the rest were underweight (17\%), overweight $(17 \%)$ and obese $(2 \%)$.

\section{Information on physical activity}

Data from questions pertaining to physical activity of students are shown in Table 3 . About $76 \%$ of students were physically-active at different levels while the remaining were not exercising. The majority of students' parents were engaged in exercises $(76 \%)$ whereas the rest did not have exercising parents. Most students (87\%) reported that even that they did not exercise at the University, they had exercised before and $82 \%$ of those who did not exercise at the university wished that they would like to exercise. The great majority of students reported that they were engaged in physical exercises prior to their admission into medical school. Data also showed that the majority of students exercised on campus (84\%) and 75\% felt that exercising facilities on campus were sufficient. Most students preferred to exercise in groups (63\%) and 21\% indicated that they exercise under supervision of a coach or by professional advice. Among exercising students, 59\% were committed to regular exercises and $78 \%$ of exercising females $(n=71)$ reported that they continued exercising during their menstrual cycle. Only $10 \%$ of the respondents represented the University of Malaya, state, national club, or the country in athletic competitions. About
$25 \%$ of students reported that they won gold, silver, bronze and medals in their sporting activity events.

Additional questions that pertain to physical activity of students are shown in Table 4. Students reported that the main reason for them to exercise is to have proper health (53\%), followed by being physically fit (29\%), and $12 \%$ just exercised for fun. The rest of the students indicated other reasons for exercising such as: utilizing free time, interest in sport, building stomata and relief of tension. The main motivating reasons for students to exercise were those of: appearance (39\%), health (29\%), friends (16\%), and self-interest (9\%). As to the types of preferred exercise/game/sport, students reported a variety of physical activities with jogging on top of such. Students pointed out a variety of positive feelings after exercising and others indicated tiredness, in contrast. As for the students who did not exercise, having either no time and/or feeling lazy were the only reasons given -62 and $38 \%$, respectively.

\section{Association between demographic parameters and physical activity}

As shown in Table 5, percentages of inactive males and females were almost equal - 52 and 48\%, respectively. Gender was a significant factor in having different levels of weekly physical activity $(\mathrm{P}<0.001)$. Student age was not a significant

Table 3: Student answers to exercise-related questions*.

\begin{tabular}{|c|c|c|}
\hline Question & $\begin{array}{l}\text { Yes } \\
\text { No. (\%) }\end{array}$ & $\begin{array}{c}\text { No } \\
\text { No. }(\%)\end{array}$ \\
\hline $\begin{array}{l}\text { Does any of your parents exercise? } \\
(n=250)\end{array}$ & $190(76.0)$ & $60(24.0)$ \\
\hline Do you exercise? $(n=250)$ & $189(75.6)$ & $61(24.4)$ \\
\hline $\begin{array}{l}\text { If you do not presently exercise, have you } \\
\text { ever exercised? }(n=60)\end{array}$ & $52(86.7)$ & $8(13.3)$ \\
\hline $\begin{array}{l}\text { Even you do not currently exercise, would } \\
\text { you like to exercise? ( }=61 \text { ) }\end{array}$ & $50(82.0)$ & $11(18.0)$ \\
\hline $\begin{array}{l}\text { Do you prefer to exercise alone? ( } \mathrm{n}=189 \text { - } \\
\text { exercising participants) }\end{array}$ & $69(36.7)$ & $119(63.3)$ \\
\hline $\begin{array}{l}\text { Do you exercise on campus? ( } \mathrm{n}=189 \text { - } \\
\text { exercising participants) }\end{array}$ & $159(84.1)$ & $30(15.9)$ \\
\hline $\begin{array}{l}\text { Are facilities sufficient on campus? ( } \mathrm{n}=159 \\
\text { - exercising on campus) }\end{array}$ & $118(74.7)$ & $40(25.3)$ \\
\hline $\begin{array}{l}\text { Did you exercise prior to being in medical } \\
\text { school? ( } n=189 \text { - exercising participants) }\end{array}$ & $179(94.7)$ & $10(5.3)$ \\
\hline $\begin{array}{l}\text { Do you exercise with a coach or under a } \\
\text { professional advice? ( } \mathrm{n}=189 \text { - exercising } \\
\text { participants) }\end{array}$ & $40(21.2)$ & $149(78.8)$ \\
\hline $\begin{array}{l}\text { Are you committed to exercising? ( } \mathrm{n}=188 \text { - } \\
\text { exercising participants) }\end{array}$ & $111(59.0)$ & $77(41)$ \\
\hline $\begin{array}{l}\text { Do you exercise during your menstrual } \\
\text { cycle? ( } n=71 \text { - exercising females) }\end{array}$ & $48(67.6)$ & $23(32.4)$ \\
\hline $\begin{array}{l}\text { Do you represent UM/State-National } \\
\text { sporting club/country? }(n=250)\end{array}$ & $25(10 \%)$ & $225(90 \%)$ \\
\hline $\begin{array}{l}\text { Were you recognized for your sporting } \\
\text { activities? }(n=250)\end{array}$ & $62(24.8)$ & $188(75.2)$ \\
\hline
\end{tabular}


Table 4: Types of exercises practiced by students and perceptions of physical activity.

\begin{tabular}{|c|c|c|}
\hline Item & No. & $\%$ \\
\hline $\begin{array}{l}\text { Why do you exercise? ( } \mathrm{n}=189 \text { ) } \\
\text { Proper health } \\
\text { Physically fit } \\
\text { For fun } \\
\text { Others }\end{array}$ & $\begin{array}{l}100 \\
54 \\
22 \\
13\end{array}$ & $\begin{array}{l}52.9 \\
28.6 \\
11.6 \\
6.9\end{array}$ \\
\hline $\begin{array}{l}\text { Why you don't exercise? (n=61) } \\
\text { No time } \\
\text { Laziness }\end{array}$ & $\begin{array}{l}38 \\
23\end{array}$ & $\begin{array}{l}62.3 \\
37.7\end{array}$ \\
\hline $\begin{array}{l}\text { Type(s) of exercise/games/sports you } \\
\text { prefer* }(\mathrm{n}=189) \\
\text { Jogging } \\
\text { Badminton } \\
\text { Swimming } \\
\text { Football } \\
\text { Basketball } \\
\text { Tennis } \\
\text { Walking } \\
\text { Others }\end{array}$ & $\begin{array}{l}51 \\
37 \\
29 \\
28 \\
22 \\
22 \\
13 \\
39\end{array}$ & $\begin{array}{l}27.0 \\
19.6 \\
15.4 \\
14.8 \\
11.6 \\
11.6 \\
6.9 \\
20.6\end{array}$ \\
\hline $\begin{array}{l}\text { How do you feel after exercise?* } \\
\text { (n=189) } \\
\text { Refreshed } \\
\text { Tired } \\
\text { Relaxed } \\
\text { Energetic } \\
\text { Fulfilled }\end{array}$ & $\begin{array}{l}77 \\
75 \\
59 \\
46 \\
44\end{array}$ & $\begin{array}{l}40.7 \\
39.6 \\
31.2 \\
24.3 \\
23.2\end{array}$ \\
\hline $\begin{array}{l}\text { What motivates you to exercise? } \\
\text { (n=189) } \\
\text { Appearance } \\
\text { Health } \\
\text { Friends } \\
\text { Self esteem } \\
\text { Others }\end{array}$ & $\begin{array}{l}73 \\
55 \\
30 \\
17 \\
14\end{array}$ & $\begin{array}{l}38.6 \\
29.1 \\
15.9 \\
9.0 \\
7.4\end{array}$ \\
\hline
\end{tabular}

factor in practicing different physical activity levels. First-year students were the majority in the all four physical activity levels - $43 \%$ for non-active, and more than $50 \%$ for the 3 levels of physical activity. Neither ethnic background nor where students came from had a significant effect on having different weekly physical activity levels. Whether students lived on or off campus did not have a significant effect on their physical activity level and neither did the number of brothers and sisters. Although respondents with working parents were of highest percentage in all active and inactive categories, there was no significant difference found between respondents with working parents comparing to those with non-working parents. All of the students who had no siblings in the University of Malay were physicallyinactive and the highest majority of students with siblings at the university were physically active at all different levels $(\mathrm{P}<0.001)$.

\section{Association between physical activity and nutrition}

Data on the relationship between nutritional factors and physical activity are shown in Table 6. There was no significant effect for whether students ate on or off campus on the physical activity level. The number of meals consumed per day was a significant factor affecting the physical activity level $(\mathrm{P}<0.02)$.
Most of the inactive students (67\%) and those with low (63\%), and medium (61\%) activity levels were having three meals per day - while $50 \%$ of those who practiced a high physical activity ate more than three meals per day. Whether students perceived that their nutrition was proper or not had no significant effect on their physical activity level. Most of the inactive students (61\%) were not taking any supplements and about half of those who were physically-active were taking supplements. There was no significant difference in physical activity level between students who were taking nutritional supplements or not. Students with normal BMI represent the majority (> 50\%) of the respondents in all four physical activity levels, showing no significant relation between BMI and the level of physical activity. Having at least one parent who exercised was a significant factor of being physically active $(\mathrm{P}<0.001)$. All participants with exercising parents were also exercising and almost all of those with non-exercising parents were not exercising (98\%).

\section{Discussion}

Being physically active is an essential part of healthy life style. Health benefits of physical activity include improved fitness, strength and overall feeling better. Therefore, all medical professionals should maintain being physically active in order to remain healthy and become role models for their patient in order to motivate them towards physical activity [18-21]. The objectives of this research were to evaluate the physical activity levels among medical students of University of Malaya, Malaysia, and to explain the factors associated with physical activity of the participants. Factors such as socio-demographic, nutritional and lifestyle habits play an important role in influencing physical activity levels.

Majority of the respondents in this study were physically active $(76 \%)$, which is in agreement with a similar finding from research work conducted by the Malaysian Ministry of health [22]. In this study, male participants were more physically-active compared to females, a finding in support by previous results of similar studies [23-27]. The participants were almost in the same age range (21.1 \pm 1.2$)$ years. Results showed no effect of student age on physical activity levels. Other studies showed that during the transition to college, exercise and fitness levels usually decrease and that they are unlikely to improve as students get older [28$30]$. The current study did not reveal any major difference in the year of study on the physical activity level of students. This can be explained on the basis that scholastic duties of all the participants were similar as they were in their preclinical stage.

The composition of the sample represented the ethnic distribution in Malaysia [31]; in particular, Malays and other Bumiputera (native) groups comprised the majority of the distribution, followed by Chinese and Indians. There was no association between the physical activity level and ethnic background. About $90 \%$ of the participants were from provinces of peninsular Malaysia and those participants were of the highest percentage in all the physical activity level groups. Unlike a previous study which showed that level of physical activity was significantly higher in students living on campus compared to 


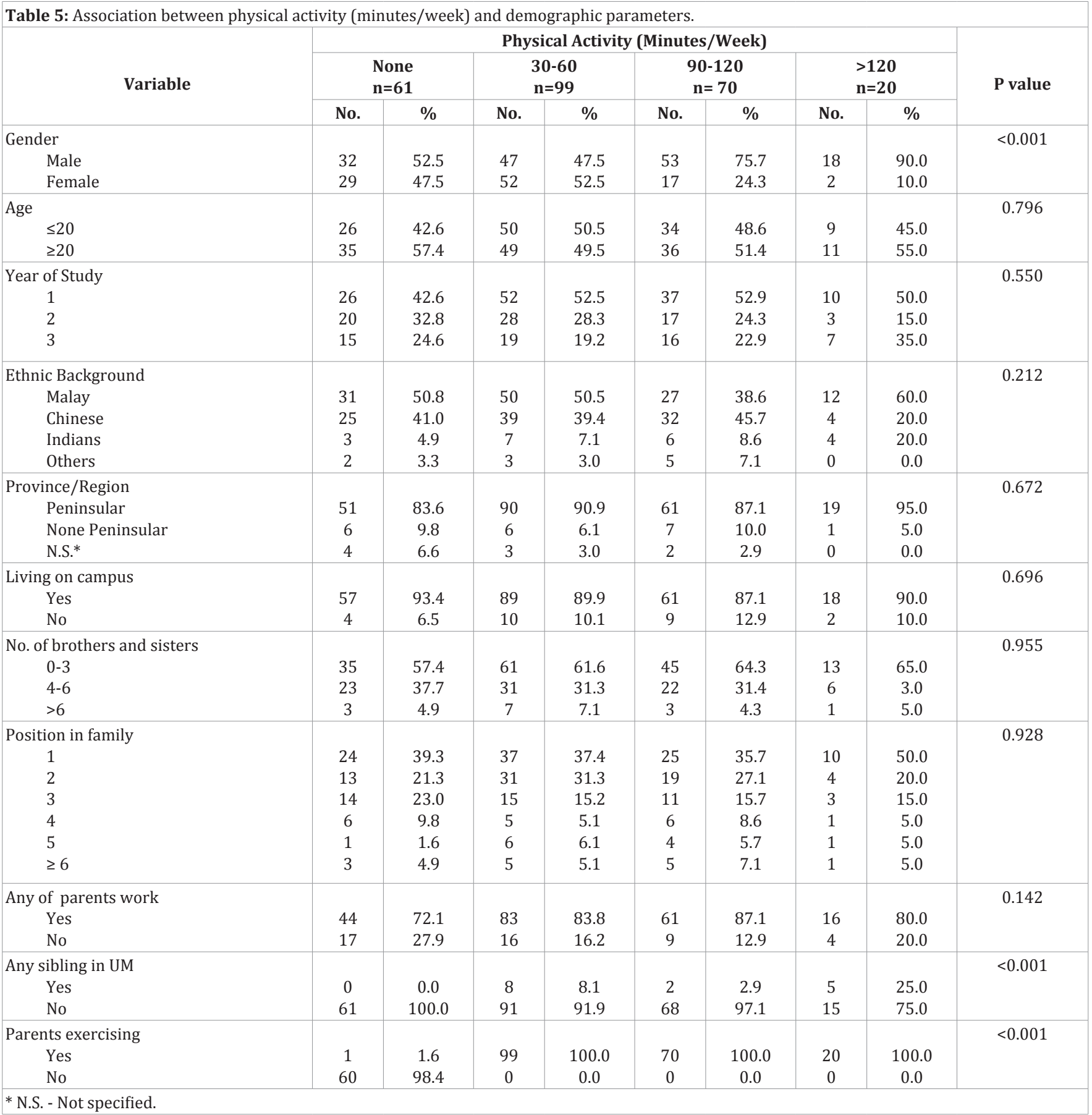

those living off campus [32], this study did not show an effect for the place of living on the physical activity level. Results showed that the student position in his/her family and the number of siblings were not influencing factors toward physical activity. The majority of the participants (82\%) were with at least one employed parent. The study showed that participants with a working parent were the majority in the four physical activity categories, 72, 84, 87 and 80\% - for none, low, medium and high physical activity levels, respectively. There was no significant effect of the parent's employment status on the physical activity of the participants. The results showed that all participants who had no sibling(s) in the University of Malaya were physicallyinactive, while none of the students who had siblings in University of Malaya were inactive $(\mathrm{p}<0.001)$. Studies have shown an important effect of family support for physical activity [33-34]. This can explain the effect of having siblings at the university - as being a form of family support.

The majority of participants in the four physical activity categories were from those dined on campus - 95, 90, 86 and $80 \%$ for none, low, medium and high physical activity levels, 


\begin{tabular}{|c|c|c|c|c|c|c|c|c|c|}
\hline \multirow[b]{3}{*}{ Variable } & \multicolumn{8}{|c|}{ Physical Activity (Minutes/Week) } & \multirow{3}{*}{$P$ value } \\
\hline & \multicolumn{2}{|c|}{$\begin{array}{l}\text { None } \\
\mathrm{n}=61\end{array}$} & \multicolumn{2}{|c|}{$\begin{array}{c}30-60 \\
n=99\end{array}$} & \multicolumn{2}{|c|}{$\begin{array}{c}90-120 \\
n=70\end{array}$} & \multicolumn{2}{|c|}{$\begin{array}{l}>120 \\
n=20\end{array}$} & \\
\hline & No. & $\%$ & No. & $\%$ & No. & $\%$ & No. & $\%$ & \\
\hline $\begin{array}{l}\text { Eating on campus } \\
\text { Yes } \\
\text { No }\end{array}$ & $\begin{array}{c}58 \\
3\end{array}$ & $\begin{array}{c}95.1 \\
4.9\end{array}$ & $\begin{array}{l}89 \\
10\end{array}$ & $\begin{array}{l}89.9 \\
10.1\end{array}$ & $\begin{array}{l}60 \\
10\end{array}$ & $\begin{array}{l}85.7 \\
14.3\end{array}$ & $\begin{array}{c}16 \\
4\end{array}$ & $\begin{array}{l}80.0 \\
20.0\end{array}$ & 0.181 \\
\hline \begin{tabular}{|c|} 
No. of meals eaten/day \\
$1-2$ \\
3 \\
$>3$ \\
\end{tabular} & $\begin{array}{c}11 \\
41 \\
9\end{array}$ & $\begin{array}{l}18.0 \\
67.2 \\
14.8\end{array}$ & $\begin{array}{l}16 \\
62 \\
21\end{array}$ & $\begin{array}{l}16.2 \\
62.6 \\
21.2\end{array}$ & $\begin{array}{c}5 \\
45 \\
20\end{array}$ & $\begin{array}{c}7.1 \\
61.3 \\
28.6\end{array}$ & $\begin{array}{c}2 \\
8 \\
10\end{array}$ & $\begin{array}{l}10.0 \\
40.0 \\
50.0\end{array}$ & 0.022 \\
\hline \begin{tabular}{|l} 
Perceived nutrition as proper \\
Yes \\
No
\end{tabular} & $\begin{array}{l}37 \\
24\end{array}$ & $\begin{array}{l}60.7 \\
39.3 \\
\end{array}$ & $\begin{array}{l}64 \\
35\end{array}$ & $\begin{array}{l}64.6 \\
35.4\end{array}$ & $\begin{array}{l}45 \\
25\end{array}$ & $\begin{array}{l}64.3 \\
35.7\end{array}$ & $\begin{array}{c}12 \\
8\end{array}$ & $\begin{array}{l}60.0 \\
40.0\end{array}$ & 0.944 \\
\hline \begin{tabular}{|l} 
Taking supplements \\
Yes \\
No
\end{tabular} & $\begin{array}{l}24 \\
37 \\
\end{array}$ & $\begin{array}{l}39.3 \\
60.7\end{array}$ & $\begin{array}{l}50 \\
49\end{array}$ & $\begin{array}{l}50.5 \\
49.5\end{array}$ & $\begin{array}{l}41 \\
29\end{array}$ & $\begin{array}{l}58.6 \\
41.4\end{array}$ & $\begin{array}{c}11 \\
9\end{array}$ & $\begin{array}{l}55.0 \\
45.0\end{array}$ & 0.170 \\
\hline \begin{tabular}{|l} 
Body Mass Index (BMI)* \\
Underweight \\
Normal \\
Overweight \\
Obese
\end{tabular} & $\begin{array}{c}13 \\
34 \\
12 \\
2\end{array}$ & $\begin{array}{c}21.3 \\
55.7 \\
19.7 \\
3.3\end{array}$ & $\begin{array}{c}19 \\
65 \\
13 \\
2\end{array}$ & $\begin{array}{c}19.2 \\
65.7 \\
13.1 \\
2.0\end{array}$ & $\begin{array}{c}7 \\
48 \\
14 \\
1\end{array}$ & $\begin{array}{c}10.0 \\
68.6 \\
20.0 \\
1.4\end{array}$ & $\begin{array}{c}3 \\
13 \\
4 \\
0\end{array}$ & $\begin{array}{c}15.0 \\
65.0 \\
20.0 \\
0.0\end{array}$ & 0.683 \\
\hline
\end{tabular}

respectively. Dining on or off campus was not a factor that influenced the level of physical activity of students. It was found that the number of meals consumed per day had a relation with the level of physical activity $(\mathrm{P}<0.02)$ in favor of having 3 meals per day. This was supported by the notion that having at least 3 meals a day allows the body to maintain a stable bodily function enabling the participants to undergo regular physical activity [35]. At least $60 \%$ of the participants perceived that their nutrition was proper, and this had no effect on their physical activity level. Whether taking or not nutritional supplements did not show any significant difference between physical activity levels of the participants. Having different BMI categories did not show any significant difference among the physical activity levels. This was supported by results obtained from other studies that did not reveal significant associations between changes in BMI and physical activity [36-37].

All students with non- exercising parents were also physicallyinactive, whereas $99.5 \%$ of participants with exercising parents were exercising at different activity levels. There was a significant difference between physical activity and having at least one parent who exercised $(\mathrm{P}<0.001)$. This association was supported by studies which revealed that families engaged in physical activity were important predictor factor of physical inactivity of adolescents [38-39]. Our findings revealed that more than $80 \%$ of inactive participants were exercising before joining medical school and expressed the desire to exercise. They explained their recent inactivity by the nature of medical school studies. Those who were engaged in physical activities preferred exercising in groups $(63.3 \%)$ and explained that having friends and socializing were their motivation factors. Many studies supported the importance of socializing as an encouraging factor for exercising [40-46]. There was no significant difference between the physical activity level and the place of exercising. Most of the students who exercised on campus (74.7\%) felt satisfied with its facilities, and the remainder of students felt that their campus lacked a satisfactory number of courts and instruments. Enjoying proper health and being physically-fit were the most motivating factors for students to exercise. Lack of time and being lazy were the major barriers for students who were not exercising, an observation that was supported by many studies showing the same results [47-49].

Data of this study revealed the status of physical activity of preclinical medical students at the University of Malaya, Malaysia, and add to other studies in the pertinent literature on this subject. Percentages of exercising and non-exercising students - as well as the levels of physical activity were expressed. Factors and conditions that influence student physical activity were explored and associations were detected. Considering that nowadays medical students will be the future medical doctors, emphasizing the significance of a healthy lifestyle for proper health of these doctors and their patients is of extreme importance. It needs to be stressed that it is of many benefits to any society that all segments of its population follow healthy dietary guidelines and be engaged in regular physical activity programs and routines.

\section{Acknowledgement}

The authors wish to thank Dr. Zoriah Aziz, Department of Pharmacy, Faculty of Medicine, University of Malaya, Kuala Lumpur, Malaysia, for providing some pertinent articles during the early stage of preparing this manuscript.

\section{Declarations}

As this was not a clinical trial, there was no need for obtaining an approval from any ethics committee or clearance at the 
University of Malaya. My co-author and I would wish to declare that there is no conflict of interest is related or associated with this study.

\section{References}

1. Global strategy on diet, physical activity and health. Geneva. World Health Organization 2010.

2. Physical activity for everyone. Atlanta, GA: Centers for Disease Control and Prevention. 2008.

3. Verhagen E, Engbers L. The physical therapist's role in physical activity promotion. British Journal of Sports Medicine. 2009;43(2):99101. doi:10.1136/bjsm.2008.053801.

4. Silliman K, Rodas-Fortier K, Neyman M. A Survey of Dietary and Exercise Habits and Perceived Barriers to Following a Healthy Lifestyle in a College Population. Californian J Health Promot. 2004;2(4):10-19.

5. Sakamaki R, Toyama K, Amamoto R, Liu C-J, Shinfuku N. Nutritional knowledge, food habits and health attitude of Chinese university students -a cross sectional study. Nutrition Journal. 2005;4(4):1-5. DOI: 10.1186/1475-2891-4-4.

6. Lobelo F, Duperly J, Frank E. Physical activity habits of doctors and medical students influence their counselling practices. British Journal of Sports Medicine. 2009;43(2):89-92. doi: 10.1136/ bjsm.2008.055426.

7. Frank E, Galuska DA, Elon LK, Wright EH. Personal and clinical exercise-related attitudes and behaviors of freshmen US medical students. Res Q Exerc Sport. 2004;75(2):112-121.

8. Stanford FC, Durkin MW, Blair SN, Powell CK, Poston MB, Stallworth JR Determining levels of physical activity intending physicians, resident and fellow physicians and medical students in the USA. Br J Sports Med. 2012;46(5):360-364. doi: 10.1136/bjsports-2011-090299.

9. Duperly J, Lobelo F, Segura C, Sarmiento F, Herrera D, Sarmiento O, et al. The association between Colombian medical students' healthy personal habits and a positive attitude toward preventive counseling: cross-sectional analyses. BMC Public Health. 2009;9:218-224. DOI: 10.1186/1471-2458-9-218.

10. Ball S, Bax A. Self-care in medical education: effectiveness of health-habits interventions for first-year medical students. Acad Med. 2002;77(9):911-917.

11. Stasiolek E, Jegier A. Physical activity in medical students. Medical News. 2003;72:140-142.

12. Krzych L. An attempt at evaluation of medical students' lifestyle. Zdr Publ. 2004;114(2):67-70.

13. Trafalska E and Grzybowski A. Risk factors in obesity and obesityrelated diseases among medical university students. Polish Journal of Human Nutrition and Metabolism. 2007;34:3-4:965-971.

14. Motylewski S, Lisowski J and Kawalec Z. The program of physical education and physical activity among last year students of the School of Medicine. Military Medicine Review. 2000;42:273-279.

15. Gromadecka-Sutkiewicz M, Chraplewska J. Rhythm of life of Poznan Medical Uni- versity students' and hygienic norms [article in Polish]. Ann Acad Med Stetin. 2005;51 Suppl 1:41-44.

16. Angyan L, Teczely T, Mezey B and Lelovics Z. Selected physical characteristics of medical students. Med Educ. 2003;8:1-6.

17. Barba C, Cavalli-Sforza T, Cutter J, Darnton-Hill I, Deurenberg, Paul, Deurenberg-Yap, et al. Appropriate body-mass index for
Asian populations and its implications for policy and intervention strategies. The Lancet. 2004;363(9403):157-163. doi: doi:10.1016/ S0140-6736(03)15268-3.

18. Angyan L. Launching kinesiology in medical education. Med Educ Online. 2000;5:8-10.

19. Rogers LQ, Bailey JE, Gutin B, Johnson KC, Levine MA, Milan F and et al. Teaching resident physicians to provide exercise counseling: a needs assessment. Acad Med.2002; 77(8):841-844.

20. Wagner PJ, Jester DM and Moseley GC. Medical students as health coaches. Acad Med2002; 77(11):1164-1165.

21. Angyan L, Fark G, Rugasi E. Trends in prevention-oriented physical education. ICSS PE Bulletin. 2002;36:10-11.

22. Healthy Life Style Campaign 2003. Malaysia Ministry of Health. Health Education Department 2003.

23. Krishnan A, Shah B, Shukla DK, Paul E and Kapoor SK. Prevalence of risk factors for non-communicable disease in a rural area of Faridabad district of Haryana . Indian Journal of Public Health. 2008;52(3):117-124.

24. Lenhart CM, Hanlon A, Kang Y, Daly BP, Brown MD and Patterson F. Gender Disparity in Structured Physical Activity and Overall Activity Level in Adolescence: Evaluation of Youth Risk Behavior Surveillance Data. ISRN Public Health. 2012;2012:1-8. doi:10.54022012674936

25. Khuwaja AK and Kadir MM. Gender differences and clustering pattern of behavioral risk factors for chronic non-communicable diseases: community-based study from a developing country. Chronic Illn.2010; 6(3):163-170. doi:10.1177/1742395309352255

26. Katulanda P, Jayawardena R, Ranasinghe P, Rezvi Sheriff $M H$, Matthews DR. Physical activity patterns and correlates among adults from a developing country: the Sri Lanka Diabetes and Cardiovascular Study. Public Health Nutr. 2013;16(9):1684-1692. doi: 10.1017/ S1368980012003990

27. Wenthe P, Janz K, Levy S. Gender similarities and differences in factors associated with adolescent moderate-vigorous physical activity. Pediatric Exercise Science. 2009;21(3):291-304.

28. Racette S, Deusinger S, Strube M, Highstein G, Deusinger R. Weight changes, exercise, and dietary patterns during freshman and sophomore years of college. Journal of American College Health. 2005;53(6):245-251.

29. Butler SM, Black DR, Blue CL, Gretebeck RJ. Change in diet, physical activity, and body weight in female college freshman. American Journal of Health Behavior. 2004;28(1):24-32.

30. Driskell J, Kim Y, Goebel K. Few differences found in the typical eating and physical activity habits of lower-level and upper-level university students. Journal of the American Dietetic Association. 2005;105(5):798-801.

31. Population Distribution and Basic Demographic Characteristics Report 2001. Department of Statistic Malaysia. 2001.

32. Lee S, Park KS. On Campus Living Increases Level of Physical Activity While Consuming More Calories. The FASEB Journal. 2008;22:877.10.

33. Aniza I, Fairuz MR. Factors Influencing Physical Activity Level Among Secondary School Adolescents in Petaling District, Selangor. Med J Malaysia. 2009;64(3):228-232.

34. Kuo J, Vorheese CC, Haythornthwaite JA, Young DR. Associations between family support, family intimacy, and neighbourhood violence and physical activity in urban adolescents' girls. American 
Journal of Public Health. 2007;97(1):101-103. doi: 10.2105/ AJPH.2005.072348

35. Davis L and Rensburg L. The hospitality industry handbook on nutrition and menu planning. Lansdowne: Juta \& Co. 2002.

36. Gonzalez-Suarez CB, Grimmer-Somers K. The association of physical activity and physical fitness with pre-adolescent obesity: an observational study in Metromanila, Philippines. J Phys Act Health. 2011;8(6):804-810.

37. He QQ, Wong TW, Du L, Jiang ZQ, Yu TS, Qiu H, et al. Physical activity, cardiorespiratory fitness, and obesity among Chinese children. Prev Med. 2011;52(2):109-113.

38. Spanier PA, Allison KR. General social support and physical activity: an analysis of the Ontario Health Survey. Can J Public Health. 2001;92(3):210-213.

39. Larsen BA, Strong D, Linke SE. The association between family and friend integration and physical activity: reslts from the NHIS. Int ] Behav Med. 2014;21(3):529-536. doi: 10.1007/s12529-013-9318-x.

40. Marquez DX, McAuley E. Social cognitive correlates of leisure time physical activity among Latinos. J Behav Med. 2006;29(3):281-289.

41. Eyler A, Brownson R, Donatelle R, King A, Brown D, Sallis J. Physical activity social support and middle- and older-aged minority women: Results from a US survey. Soc Sci Med. 1999;49(6):781-789.

42. Eyler A, Wilcox S, Matson-Koffman D, Evenson KR, Sanderson B, Thompson J, et al. Correlates of physical activity among women from diverse racial/ethnic groups. Journal of Women's Health \& Gender Based Medicine. 2004;11(3):239-253.

43. Trost SG, Owen N, Bauman AE, Sallis JF, Brown W. Correlates of adults' participation in physical activity: review and update. Med Sci Sports Exerc. 2002;34(12):1996-2000.

44. Courneya K, Plotnikoff R, Hotz S, Birkett N. Social support and the Theory of Planned Behavior in the exercise domain. American Journal of Health Behavior. 2000;24(4):300-308.

45. Amesty S. Barriers to physical activity in the Hispanic community. J Public Health Policy. 2003;24(1):41-58.

46. Stahl T, Rutten A, Nutbeam D, Bauman A, Kannas L, Abel T, et al. The importance of the social environment for physical activity lifestyle: Results from an international study. Soc Sci Med. 2001;52(1):1-10.

47. Sajwani R, Shoukat S, Raza R, Shiekh M, Rashid Q, Siddique M, et al. Knowledge and practice of healthy lifestyle and dietary habits in medical and non-medical students of Karachi, Pakistan. Journal of the Pakistan Medical Association. 2009;59(9):650-655.

48. El-Gilany A, El-Masry R. Physical inactivity among Egyptian and Saudi medical students. TAF Prev Med Bull. 2011;10(1):35-44.

49. Awadalla NJ, Aboelyazed AE, Hassanein MA, Khalil SN, Aftab R, Gaballa II. Assessment of physical inactivity and perceived barriers to physical activity among health college students, south-western Saudi Arabia. Eastern Mediterranean Health Journal. 2014;20(10):596604. 